space to those already considered, it is only because he is necessarily more familiar with that material.

Dr. P. M. T. Kerridge dealt with the history and causes of deafness in London children in schools for the deaf. It is interesting to note from her analysis that, in the severely deaf group, almost half had been deaf from birth. Miss E. L. S. Ross discussed and analysed the results of an experiment in which a short story was read to two small groups of partially or severely deaf children, first without and secondly with an electrical aid of commercial manufacture. The children's reproductions of this story were marked according as they had, for example, grasped or missed the point, or understood or misunderstood the name of the central character. She showed that only with some of the children was a partial improvement of understanding secured by these means.

A. F. RAWDON-SMITH.

\title{
Ability, Opportunity and Social Status
}

$\mathrm{I}^{\mathrm{N}}$ $\mathrm{N}$ a paper entitled "Ability and Educational Opportunity in Relation to Parental Occupation", which appears in the Sociological Review (27, No. 3, July 1935), J. L. Gray and Pearl Moshinsky bring forward evidence to show that the children of the less prosperous social classes lack the opportunity for higher education available to the equally able children of the financially prosperous classes. The investigation on which the evidence is based was carried out on nearly 9,000 children, between the ages of 9 years and 12 years 6 months, drawn from primary, post-primary (including central), grantaided secondary, private, and preparatory schools in the London area, during the year 1933-34. Individual ability was assessed by the Otis Advanced Group Intelligence Test (Form $A$ ), and each child was questioned individually regarding parental occupation.

The authors point out that every attempt at morphological classification in social orders presupposes a social philosophy and a knowledge of the causes of social differentiation. The classification finally adopted by them represents a compromise between several current systems. The basis of group differences is taken as the nature of the work performed, but is modified "where it seemed advisable" by combination with differences in average income and in social status: the six main groups thus obtained are relatively homogeneous. They are: $(A)$ Employing and Directive Classes; (B) Professional Classes ; $(C)$ Minor Professional and Other Highly Skilled Occupations ; $(D)$ Clerical and Commercial Employees; $(E)$ Manual Workers; and $(F)$ Miscellaneous Workers and Unknown Occupations.

The significant differences in educational opportunity between these socio-economic categories, revealed by the final analysis, certainly confirm the authors' belief that the groups do constitute real socio-economic strata.

It is evident that this classification correlates to some extent both with parental intelligence and with nurtural and environmental factors in the life of the child. The acceptance of the genetic evidence that highly intelligent parents tend to produce highly intelligent children, or the acceptance of the doctrine that nurture is the dominant factor in intellectual development, leads to the expectation of a small positive correlation between the intelligence of the child population examined and the parental socio-economic status. The value found by the authors is $0.25 \pm 0.008$, a value which is, however, too small to be used diagnostically. This value compares favourably with the value $0 \cdot 28$ found by Duff and Thompson* in an investigation of the

* Brit. J. Psychol., 14, Pt. 2; 1924. parallel problem in Northumberland ten years ago. As the authors state (but not only for the reasons quoted) it is unwarranted to assert, by reason of the existence of the positive correlation, that intelligence is causally related to parental socio-economic status.

Some of the results of the primary analysis deserve special reference :

(1) In all cases, the children of teachers of every kind exceed the mean of the social group of highest intelligence. This is, perhaps, not surprising in view of the construction of the test used to obtain differentiæ.

(2) The children of the 'larger business owners and higher executives group' are significantly inferior in mean intelligence to those of the professional classes. Nearly every other investigator has arrived at this conclusion.

(3) It is probable that children of manual workers engaged in the newer industries, where, for example, considerable mechanical ability is demanded, are superior in mean intelligence to those of all manual workers.

(4) The children of unskilled workers form a remarkably homogeneous group.

In the ultimate analysis of their material, the authors make a comparative study of the distribution among the various social orders of the opportunity for higher education and of the corresponding distribution of high ability, that is, ability to benefit from higher education, the lower level being taken at 130 I.Q. on the Otis scale or 120 I.B. (Index of Brightness) on the authors' scale. As a source of children of high ability, the 'manual workers group' is the largest numerically, although it contains the smallest percentage of able children within the group. Thus, 58 per cent of the children of the 'professional classes group' possess ability, and 23 per cent of the children of 'manual workers group' are equally able; but in terms of the ratio of able children in the group to the total of all able children, these figures are 5 per cent and 50 per cent.

The discrepancies between ability and opportunity are shown by the following figures : 95 per cent of the able children of the 'professional classes group' have the opportunity for higher education; 48 per cent of the able children of the 'clerical and commercial employees group' have the same opportunity ; only 25 per cent of the able children of the 'manual workers group' receive the same facilities. Opportunity for higher education is wasted most by the children of the 'larger business owners and higher executives' and of the 'professional classes groups'. There are 49 per cent of the former and 35 per cent of the latter, in each group, with opportunity but 
without ability. In the case of children selected by competitive examination at the age of 11 plus, only $1 \cdot 0$ per cent have the opportunity for higher education without having the ability to benefit by it.

These figures reveal striking differences between the educational opportunities available for children of equal ability but of parents of different social status; and these differences are inherent in the present social system. That is to say, they belong to nurture and not to nature. It might be added, in comment, that the validity of these results depends on the extent to which the intelligence test measures the ability of the child to benefit from the higher education of the type provided in secondary schools. This is a matter which some educationists would be prepared to debate.
W. F. FLOYD.

\section{Tell el-Amarna, I934-5}

\begin{abstract}
$\mathrm{A}^{\mathrm{N}}$ exhibition of finds from Tell el-Amarna, results $\mathrm{A}^{\mathrm{N}}$ oxhibition of the Egypt Exploration Society's expedition during the season 1934-5, opened at the rooms of the Palestine Exploration Fund, 2, Hinde Street, London, W.1, on September 16, and will remain on view until October 12. Further progress has been made in the excavation of the Royal Palace. Its total length has not yet been ascertained, as exploration has not proceeded beyond the modern road, but it is expected that it will fall not far short of a kilometre.
\end{abstract}

Operations of the season concentrated on the great hall at the south end of the building, the harem quarter, and the state approach, paved with plaster, which runs on the western side of the harem to the 'Broad Hall'. Advantage was also taken of an opportunity to make a record in tracings and photographs of the sculptured reliefs in the Royal Tomb, which lies in a valley about four miles away. This is the burial place of the young Princess Maketaten, one of the daughters of Akhenaten (1387-70 B.c.), religious reformer and builder of Tell el-Amarna. No complete record of these reliefs has been made before, and owing to the fitting of a new doorway, the opportunity will not recur. The drawings from the tracings have not yet been completed; but the series of photographs, which show the representations of intimate scenes of mourning, including a visit of the Royal Family to the temple, forms part of the exhibit of plans and photographs, which illustrate the progress of the excavations and the character and extent of the building.

Although the finds of the season included several of striking interest, the total number of exhibits is not large. This is due to the fact that a large amount of the expedition's time was absorbed by the deep digging necessitated in the area of the approach way to the 'Broad Hall'. Here a large building, called the
'Shining of the Aten', and part of the approach had been demolished early in the reign of Akhenaten. The whole area had then been filled in with sand to a depth of ten feet and levelled to form a parade ground.

In this filling were found many fragments of the sculpture of the original building, which could not be used elsewhere. Hence the sculptures have preserved all their freshness. Among the selection shown are some singularly striking examples of graphic representation, such as, in particular, spirited horses, soldiers and servants bowing, a fine royal head, and two heads with arrogant expression, here labelled 'priests'. The approach way itself has yielded thousands of fragments of the rows of huge granite and quartzite statues with which it was adorned. These were systematically broken up at the time of the destruction of the city after the death of Akhenaten and the overthrow of his reformed religion.

In the harem quarter, with its garden surrounded by a colonnade carved with festoons of birds, one of the most notable finds was the model of a fish in gold plate, which may have formed a part of the decoration of a formal pond, or have been a royal toy. It is shown only by a photograph, the original remaining in Cairo. One of the most interesting portions of the Palace as yet explored is the great hall at the south end of the building. Its vast roof was supported by a forest of brick piers, and it was decorated with faience tiles. Complete examples of these are now shown for the first time. They show naturalistic flower designs with white daisies in faience inlaid. It is hoped that it may be possible to com. plete the excavation of the Palace in the coming season. This, however, must depend entirely upon the extent to which further financial assistance towards the cost of excavation can be obtained from subscription by the public.

\section{The Bihar Earthquake of 1934}

GOON after the occurrence of this great earthquake on January 15, Dr. J. A. Dunn and three assistants were sent to the areas chiefly affected. A preliminary report on the earthquake by Messrs. J. B. Auden and A. M. N. Ghosh has recently been published (Rec. India Geol. Surv., 68, 177-239; 1935). A brief report has also been written by Mr. N. Nasu (Bull. Earthq. Res. Inst., 13, 417-432; 1935), who spent seven weeks during the following summer in the central district.

Owing to the occurrence of the earthquake at about 2.13 p.m., the loss of life was much less than might have been expected from the damage to property. Including Nepal, more than 10,000 lives were lost, mainly in the crowded towns of Monghyr, Muzaffarpur and the Nepal valley. The isoseismal of highest 